Info Artikel:

\title{
Fenomena LGBTQ dalam perspektif konseling dan psikoterapi: realitas dan tantangan konselor
}

\author{
Zadrian Ardi ${ }^{1}$, Frischa Meivilona Yendi ${ }^{2}$, Rahmi Dwi Febriani ${ }^{3}$ \\ ${ }^{123}$ Universitas Negeri Padang
}

\begin{abstract}
Kondisi penyimpangan orientasi seksual merupakan kondisi individu yang tidak muncul dalam unifaktor, dengan kata lain kondisi tersebut berkembang akibat dari berbagai faktor dalam rentang kehidupan individu. Kondisi penyimpangan orientasi seksual yang saat ini populer dengan LGBTQ (Lesbian, Gay, Bisexual, Transgender dan Queer) merupakan fenomena yang selalu muncul dalam setiap komunitas masyarakat yang dalam beberapa tahun ini hak dan kekebasannya tengah lantang disuarakan oleh beberapa negara maju. Hal ini tentu saja menimbulkan permasalahan dan polemik dalam dimensi kehidupan, tak terkecuali dalam kehidupan klien. Konselor sebagai pekerja sosial yang dapat bersentuhan langsung dengan kondisi ini merupakan pihak yang hendaknya memiliki langkah konkrit dalam penanganannya, baik langkah preventif maupun langkah kuratif melalui pelayanan konseling dan psikoterapi. Sudut pandang konseling dan psikoterapi dalam penanganan permasalahan ini merupakan salah satu titik kunci yang dapat dijadikan pendekatan awal. Selain itu, langkah konkrit dalam pelayanan konseling diharapkan mampu menjadi jalan keluar bagi klien untuk berkehidupan yang membahagiakan, mandiri dan memiliki pengendalian diri.
\end{abstract}

Keywords: orientasi seksual, LGBTQ, konseling, psikoterapi

(c) (i) This is an open access article distributed under the Creative Commons Attribution License, which permits unrestricted use, distribution, and reproduction in any medium, provided the original work is properly cited. C2018 by author.

\section{PENDAHULUAN}

Perkembangan teknologi, sains, komunikasi dan keilmuan lain membawa pengaruh pada terjadinya diferensiasi sosial dan peran dalam dimensi bermasyarakat. Akses informasi yang begitu mudah menjadi salah satu faktor cepatnya proses persilangan budaya dari berbagai daerah bahkan negara, yang pada akhirnya membuka peluang munculnya pola-pola perilaku yang berbeda di masyarakat. (Pontororing, 2012). Hal ini tak terkecuali terjadi di Indonesia dengan budaya, demografi, tingkat pendidikan dan status sosial ekonomi yang sangat beragam. Perbedaan tersebut menjadi wajar dengan pertumbuhan penduduk yang cukup pesat hingga kini berjumlah sekitar 220 juta jiwa dan tersebar pada sekitar 6000 pulau dengan keragaman bahasa sebanyak 700 jenis bahasa lokal (Boellstorff, 2004).

Berbagai aspek permasalahan sosial dapat muncul sebagai kompensasi dari perkembangan tersebut. Diantara masalah yang belakangan mendapat perhatian khusus dan kontroversi di kalangan praktisi, akademisi maupun masyarakat luas adalah permasalahan orientasi seksual yang menyimpang, dimana kondisi ini belum mendapat kesepakatan dari masyarakat luas, khususnya Indonesia (Siregar, 2013). Kemenyimpangan ini pada dasarnya bukan merupakan barang baru dalam realita kehidupan sosial kemasyarakatan, namun permasalahan ini kembali mencuat ke permukaan dan mengundang berbagai reaksi setelah pengesahan perkawinan sejenis oleh Mahkamah Agung Amerika Serikat (BBC News, 2015). Orientasi seksual yang menyimpang tersebut secara eksplisit dikategorikan dalam Lesbian, Gay, Bisexual, Transgender dan Queer (LGBTQ).

Apabila dilihat dari populasi LGBTQ yang membutuhkan perhatian dan penanganan tersebut terlihat dari paparan data yang menunjukkan bahwa setidaknya terdapat $2 \%-13 \%$ dari populasi dunia merupakan individu 
yang memiliki orientasi seksual tersebut, dan $60 \%$ diantaranya merupakan anak-anak muda (Dank, Lachman, Zweig, \& Yahner, 2014; Rhomadona, 2012; Sumadi \& Wahyu, 2013). Untuk wilayah Indonesia sendiri, berbagai riset pada tahun 2014 memperkirakan bahwa pengidap LGBTQ adalah sebanyak 1\% dari total populasi rakyat Indonesia dan diperkirakan angka ini akan terus bertambah setiap tahunnya (Azmi, 2015). Selain penduduk Indonesia yang tinggal di negerinya sendiri, pengidap orientasi seksual LGBTQ juga dialami oleh tenaga kerja Indonesia di luar negeri dengan angka pengidap yang cukup banyak. Pada tahun 2013 ditemukan $84,45 \%$ tenaga kerja Indonesia yang bekerja di Hongkong adalah lesbian dan tidak sungkan untuk menunjukkan orientasi seksualnya tersebut di depan umum (Afifah, 2015).

Apabila dilihat dari sudut pandang sosiologi dan patologi sosial, homoseksual dapat didefinisikan sebagai kecenderungan seseorang yang lebih mengutamakan orang dengan jenis kelamin yang sala sebagai mitra dalam memenuhi kebutuhan libido dan mitra dalam hubungan seksual (Fifi, 2015). Walaupun demikian, tidak ditemukan adanya faktor tunggal yang menjadi penyebab seseorang tertular kondisi LGBTQ tersebut, karena faktor pembentuk perilaku LGBTQ merupakan gabungan dari berbagai faktor; diantaranya adalah faktor biologis, psikologis, dan sosial, selain itu adanya pengaruh lingkungan yang berdampak buruk pada kematangan seksual yang normal serta pengaruh pola asuh orangtua (Sumadi \& Wahyu, 2013).

Kecenderungan seksual menyimpang yang diidap oleh populasi khusus ini membawa pergerakan yang cukup spesifik dalam rangka menunjukkan eksistensi mereka. Hal ini terwujud dalam bentuk mulai maraknya majalah-majalah, website dan program berbasis teknologi lain yang menunjukkan eksklusivitas populasi mereka (Juditha, 2014). Peluang ini ditanggapi dengan baik dengan analisis bahwa dengan sasaran pembaca yang spesifik dan khusus, maka media yang menyebarkan informasi dan media yang bebas mengekspresikan diri tersebut akan tetap bertahan meskipun akan ada goncangan dari pihak lain. Dengan adanya media, kaum minoritas LGBTQ akan memperlihatkan posisi yang semakin kukuh dan penguatan kepada audiens mereka (Juditha, 2014).

Selain itu, realitas yang muncul di lapangan adalah seringkali ditemukan dalam lingkungan kampus beberapa mahasiswi yang berpenampilan maskulin dengan memakai celana jeans pria, memakai kemeja atau kaos, sepatu sports dan model rambut pendek persis seperti mahasiswa kebanyakan (Saputra, 2015). Kondisi ini jelas merupakan salah satu indikator yang menjadi tolok ukur dalam mengekspresikan diri bagi kaum minoritas ini, terlepas dari stigma dan prejudice terhadap individu yang mengekspresikan diri demikian. Atau bagi kasus biseksual, mayoritas pengidapnya adalah laki-laki yang bahkan telah berkeluarga dan memiliki anak memiliki orientas seksual ganda (Siregar, 2013). Kondisi tersebut jelas merupakan fenomena yang harus mendapat perhatian khusus dari berbagai pihak. Temuan lain juga menunjukkan fakta bahwa mayoritas pengidap LGBTQ merupakan anak muda dengan rentang umur antara $17-22$ tahun dengan status sebagai mahasiswa dan siswa (Arsita, 2014).

Berpedoman kepada temuan di lapangan dan paparan fakta hasil penelitan mengenai kondisi LGBTQ maka konselor sebagai salah satu profesi yang diakui pemerintah dalam penanganan klien diharapkan mampu menjadi pihak yang bisa melayani klien dengan berbagai latar belakang budaya, nilai dan norma (Azmi, 2015). Selain itu, konselor sebagai seorang pendidik (Kementerian Pendidikan Nasional, 2003) juga memiliki tanggung jawab untuk menyelenggarakan pelayanan konseling demi tercipatanya kondisi efektif sehari-hari (Ardi, 2012).

\section{Penolakan Masyarakat dan Resiko-resiko Pengidap LGBTQ}

Masyarakat memandang kondisi permasalahan LGBTQ dengan berbagai sudut pandang, sebagian besar menganggap bahwa penyimpangan orientasi seksual merupakan pelanggaran terhadap norma-norma yang umum berlaku dan sebagian lain menganggap bahwa kecenderungan ini adalah suatu gaya hidup (Rhomadona, 2012) sehingga kontroversi masih bermunculan mengenai pengesahan pernikahan sejenis tersebut. Salah satu realita LGBTQ yang sering muncul dalam lapisan kehidupan masyarakat adalah kehadiran banci. Banci dapat didefinisikan sebagai suatu sebutan untuk seorang laki-laki yang menjadi seorang wanita, baik secara perilaku maupun penampilan (Boellstorff, 2004). Pada kenyataannya, keberadaan banci masih menimbulkan berbagai pro dan kontra pada masyarakat.

Selain itu, berbagai reaksi yang muncul atas kemunculan kaum homoseksual salah satunya disebabkan tatanan sosial masyarakat Indonesia mengajarkan nilai-nilai heteronormatif yang memiliki asumsi bahwa heteroseksualitas merupakan satu-satunya norma yang dikatakan normal serta pantas, sehingga suatu hubungan/nilai seksualitas dianggap normal apabila saling melengkapi antara antara laki-laki dan perempuan (Mariani, 2013; Yuwono, 2013). Sehingga dengan hadirnya beberapa individu yang menyimpang dari autran normal masyarakat akan mengundang konflik, hinaan, stigma dan prasangka negatif baik dari lingkungan keluarga maupun masyarakat (Mariani, 2013; Saputra, 2015). Hal ini tentu saja akan membuat orang-orang 
terdekat individu dimaksud akan menjauh dengan jalan mengasingkan atau mengucilkan keberadaan kaum minoritas ini (Mariani, 2013).

Terdapat beragam dampak dari pandangan masyarakat terhadap kaum minoritas pengidap LGBTQ. Kondisi yang justru membuat para pengidap kondisi ini tetap menjalin hubungan sejenis dengan cara sembunyi-sembunyi (Siregar, 2013) maupun dengan membuat sebuah komunitas eksklusif. Kelompok-kelompok eksklusif ini diwadahi secara online maupun organisasi yang telah terstruktur. Penjaringan anggota dengan media online dilakukan di berbagai media sosial, salah satu diantaranya adalah grup facebook (Arsita, 2014). Selain itu, perkumpulan tersebut juga diwadahi dengan pembangunan website komunitas, beberapa diantaranya adalah Gaya Nusantara, Prewakos, Savy Amira dan lain sebagainya (Saputra, 2015). Grup yang lebih terorganisir juga dibuat secara eksklusif dengan memanfaatkan berbagai pusat-pusat keramaian seperti mall, tempat karaoke, bioskop dan sebagainya sebagai tempat berkumpul (Arsita, 2014).

Melihat realitas tersebut, hal ini ini merupakan dampak simultan dari persepsi masyarakat umum tentang cara pandang dan penanganan terhadap kaum pengidap LGBTQ tersebut. Tentu saja hal ini akan membawa berbagai dampak dan resiko bagi pengidap LGBTQ (Vitasandy, 2010) baik dari segi psikologis maupun fisiologis.

Resiko seseorang dengan kondisi LGBTQ adalah rendahnya self-esteem dan konsep diri. Faktor pandangan lingkungan masyarakat terhadap pengidap LGBTQ akan membentuk perasaan kurang berarti pada diri individu (Vitasandy, 2010). Apabila hal ini terus dialami oleh individu, maka akan membawa dampak berupa stres dan depresi. Resiko dari perlakuan masyarakat dan kondisi minoritas tersebut akan membawa individu pada perasaan tertekan dan perasaan terdiskriminasi sehingga memunculkan kondisi depresi (Gattis, Woodford, \& Han, 2014).

Selain masalah depresi dan stress, seseorang yang mengidap kelainan orientasi seksual akan memiliki resiko permasalahan kesehatan reproduksi yang lebih besar. Berdasarkan hasil penelitian di salah satu kota di Indonesia menyebutkan bahwa lebih dari 50\% pengidap lesbian yang memiliki pengetahuan yang memadai mengenai resiko melakukan hubungan sejenis (Rhomadona, 2012), hal ini tentu akan membuka peluang penyebaran penyakit menular seksual yang lebih tinggi diantara pengidap LGBTQ (Ardi \& Yendi, 2017).

Individu yang mengidap orientasi seksual berupa LGBTQ memiliki resiko kekerasan seksual lebih tinggi dibandingkan dengan individu yang memiliki kecenderungan heteroseksual (Gattis et al., 2014; Richardson, Armstrong, Hines, \& Palm Reed, 2015). Hal ini terjadi karena apabila seseorang pengidap LGBTQ mengalami kekerasan secara seksual, maka korban tidak akan mau melaporkan hal tersebut sebab pada akhirnya korban akan tetap dipersalahkan atas kondisi yang menimpanya (Richardson et al., 2015). Berbagai bentuk kekerasan seksual dapat dialami oleh pengidap LGBTQ, diantaranya adalah kekerasan fisik dalam hubungan seksual, kekerasan psikologis, kekerasan cyber dan paksaan untuk melakukan hubungan seksual, bahkan kebanyakan korbannya adalah anak-anak muda dan remaja (Dank et al., 2014).

Apabila dilihat dari gender, wanita lebih banyak mengalami kekerasan seksual dibandingkan dengan pengidap LGBTQ laki-laki (Dank et al., 2014), dimana selain mengalami kekerasan seksual wanita yang memiliki kecenderungan homoseksual juga menjalani pola hidup tidak sehat diantaranya merokok 4,9 kali lebih banyak dari wanita heteroseksual, dan 10,7 kali lebih banyak meminum alkohol dari wanita heteroseksual (Dank et al., 2014; S.L. et al., 2006). Hal ini jelas akan membawa dampak pada kondisi kesehatan penderita LGBTQ secara umum.

Dengan kata lain permasalahan kelainan orientasi seksual pada individu akan membawa pada dampakdampak serius dari segi psikologis dan fisik. Bahkan secara umum, pengidap LGBTQ akan merasakan marjinalisasi ekonomi, diskriminasi politik, pelecehan seksual, pemerkosaan, kekerasan dalam rumah tangga, penganiayaan dan pembunuhan (Pontororing, 2012), dan lebih jauh lagi tidak tertutup kemungkinan korban dari kondisi ini suatu saat akan menjadi pelaku.

\section{Pandangan Konseling dan Psikoterapi}

Penanganan kondisi klien yang mengidap LGBTQ dikategorikan dalam populasi khusus (Allan, Tebbe, Duffy, \& Autin, 2015). Hal ini dikarenakan tidak seluruh individu akan merasakan dan mengalami kondisi ini, dan hanya karena faktor-faktor tertentulah seseorang mengalami perubahan orientasi seksual. Berbagai permasalahan yang dialami pengidap LGBTQ membutuhkan penanganan khusus oleh konselor, terlebih hal ini menyangkut kondisi kehidupan klien khususnya berupa marginalisasi, gangguan dalam berkarir, norma dalam masyarakat serta keyakinan beragama (Allan et al., 2015; Gattis et al., 2014) 
Penanganan konseling pada klien yang mengidap LGBTQ menjadi sangat krusial karena lebih dari $60 \%$ pengidap kecenderungan orientasi seksual ini merasa tidak aman dan nyaman ketika pergi ke sekolah, dan banyak diantaranya memiliki gejala depresi, self-esteem rendah, bolos sekolah dan hasil belajar rendah (Dank et al., 2014). Selain itu, beberapa riset mengemukakan bahwa terjadinya luka batin yang dialami penderita LGBTQ menjadi salah satu penyebab seseorang memiliki kecenderungan orientasi seksual menyimpang (Sumadi \& Wahyu, 2013) sehingga kondisi luka tersebut perlu penanganan konselor. Kondisi lain yang mesti menjadi perhatian bagi konselor adalah kondisi in order motive pengidap LGBTQ yang mengarah pada keinginan untuk kembali memiliki orientasi heteroseksual atau menjadi normal dalam pandangan masyarakat (Saputra, 2015).

Mengingat di beberapa negara maju di dunia telah mengkategorikan perilaku orientasi seksual LGBTQ tidak lagi merupakan gejala penyimpangan (telah dinyatakan keluar dari DSM IV) dan tidak tercantum lagi dalam laporan kesehatan WHO (World Health Organizaton, 2001) maka hal ini bermakna bahwa secara global, tidak banyak yang akan mengkaji penanganan atau pengentasan perilaku ini. Namun hal ini tentu tidak berlaku dalam kebudayaan Indonesia. Adat ketimuran dari Indonesia menganggap bahwa perilaku LGBTQ merupakan sesuatu yang dianggap "tidak normal" (Azmi, 2015) dan membutuhkan penanganan khusus. Tentu saja konselor di Indonesia, dan seharusnya bersikap arif terhadap norma yang berlaku harus mengambil peran dalam upaya ini.

Munculnya fenomena LGBTQ yang saat ini sudah mulai terlihat ke permukaan seperti gambaran gunung es yang masih membutuhkan upaya untuk penelusuran lebih mendalam (Azmi, 2015) salah satunya yang dilakukan oleh konselor. Konselor sebagai pendidik (Kementerian Pendidikan Nasional, 2003) pada hakikatnya memiliki tanggung jawab dalam memelihara kaidah-kaidah pendidikan nasional dalam setiap pelayanannya, salah satunya adalah dalam penanganan perilaku orientasi seksual menyimpang. Selain itu, pendidikan yang salah satunya berlandaskan pada penanaman nilai-nilai karakter-cerdas (Marjohan, 2012) juga tidak sesuai dengan kondisi LGBTQ.

\section{Langkah Preventif dan Kuratif}

Banyak faktor yang menjadi penyebab seseorang mengalami perubahan orientasi seksual. Faktor tersebut diantaranya peran sosialisasi serta nilai spiritual yang rendah dalam lingkungan keluarga, selain itu adanya faktor pergaulan dan interaksi sosial teman sebaya yang terlebih dahulu memiliki kecenderungan LGBTQ tersebut (Sumadi \& Wahyu, 2013) ditambah lagi dengan kenyataan bahwa pengidap LGBTQ pada umumnya melakukan hubungan dengan sembunyi-sembunyi (Siregar, 2013).

Penelitian-penelitian terdahulu banyak mengungkapkan bahwa terjadi stigma dan prasangka negatif terhadap keberadaan kaum minoritas LGBTQ sehingga hal ini akan berpengaruh terhadap cara mereka bersikap (Worthen, 2012). Lebih jauh lagi, kondisi kekurangan informasi yang memadai tersebut memunculkan suatu stigma dan kondisi ketakutan tertentu berupa homophobia, bi-phobia, dan trans-phobia dalam masyarakat (Worthen, 2012). Kondisi tabu dan ketidaktahuan ini menjadi salah satu penyebab mengapa sulit untuk melakukan langkah pencegahan seseorang terjerumus dalam perilaku orientasi seksual menyimpang maupun langkah pengentasannya.

Berbagai langkah pencegahan (preventif) dapat dilakukan agar seorang individu tidak terjerumus dalam perilaku LGBTQ. Penyelenggaraan pelayanan konseling dengan landasan terciptaya kehidupan sehari-hari adalah salah satu langkah yang dapat dilakukan (Marjohan, 2012), pelayanan dimaksud dilaksanakan dalam ranah pengembangan tujuan hidup individu, peningkatan kompetensi diri, serta terimplementasikannya nilainilai moral dalam kemandirian dan pengendalian diri. Langkah lain yang dapat dilakukan untuk mencegah penularan kondisi LGBTQ adalah peningkatan peran keluarga dalam menjaga reliabilitas fungsi-fungsi moral pada anak. Hal ini merupakan hal penting karena apabila kondisi keluarga tidak kondusif (buruknya komunikasi, lemahnya kontrol orangtua, kurangnya penanaman nilai-nilai moral) akan berdampak pada mudahnya individu (anak) terjerumus dalam kondisi LGBTQ (Sumadi \& Wahyu, 2013). Selanjutnya adalah adanya peran pemerintah dalam mencegah munculnya kasus-kasus LGBTQ dalam masyarakat. Pemerintah pada dasarnya perlu melakukan berbagai upaya untuk mempertahankan budaya-budaya luhur bangsa melalui berbagai regulasi dan agenda untuk mencegah perilaku homoseksual (Afifah, 2015).

Selain langkah pencegahan, pengentasan perilaku LGBTQ juga dibutuhkan untuk individu yang sudah terlanjur memiliki orientasi seksual menyimpang dimaksud. Pelayanan konseling dengan segenap bidang pengembangan (Ardi, 2012) merupakan salah satu upaya untuk mengentaskan perilaku ini. Bidang yang bersinggungan langsung dengan kondisi LGBTQ ini adalah bidang pribadi, dimana seluruh dimensi kepribadian individu merupakah daerah kajian dalalm proses pelayanan konseling secara menyeluruh. Selain itu, berbagai pendekatan dalam konseling dapat diterapkan dalam pengentasan permasalahan ini, diantaranya dengan penerapan enam kontinum dasar dalam pelayanan konseling transgender (Azmi, 2015). Praktik psikoterapi juga 
salah satu cara untuk pengentasan permasalahan ini yang dapat dilakukan oleh konselor (Ardi, Putra, \& Ifdil, 2017; Ardi, Viola, \& Sukmawati, 2018). Pelayanan dengan menggunakan pendekatan hipnoterapi akan membantu klien dalam mendalami diri, mengenal diri dan lingkungan serta nilai-nilai yang didalaminya selama ini (Kahija, 2007). Dengan mendalami klien tersebut, maka konselor dapat menetapkan langkah-langkah penanganan yang tepat dan efisien (Ardi \& Sukmawati, 2017).

Pendekatan lain yang bisa dilakukan adalah dengan Art Therapy. Pada beberapa kasus, klien bisa tidak terbuka kepada klien dan kurang mampu melakukan komunikasi yang baik berkenaan dengan kasus yang dialami, sehingga membutuhkan suatu media untuk melakukan pendalaman terhadap kondisi demikian (Rubin, 2010). Dengan hasil yang cukup signifikan, pendekatan ini dapat dijadikan salah satu altenatif penanganan kondisi LGBTQ pada diri klien yang mungkin kurang mampu mengungkapkan permasalahannya. Pengetahuan dan pendalaman awal mengenai kondisi klien dengan kecenderungan homoseksual dapat dilakukan dengan analisis gambar melalui terapi ini (Davido, 2012), yakni ketika seseorang anak (atau juga dapat berlaku untuk orang dewasa) yang cenderung langsung menggambar orang dengan jenis kelamin yang sama meskipun diminta untuk menggambar bebas.

\section{KESIMPULAN}

Pada hakikatnya, fenomena LGBTQ dalam masyarakat Indonesia bukan merupakan hal baru dan sudah berlangsung sejak lama. Namun hal ini mulai secara aktif muncul ke permukaan setelah adanya pergerakanpergerakan nyata dari kelompok-kelompok LGBTQ di negara-negara maju. Hal ini tentu memotifasi pergerakan yang sama di Indonesia. Hal ini terbukti dengan temuan adanya kelompok-kelompok LGBTQ yang mulai aktif di media sosial dan propaganda di media lainnya.

Konselor sebagai seorang pendidik tentu memiliki tantangan dalam penanganan permasalahan ini. Mengingat kondisi LGBTQ merupakan penyimpangan orientasi seksual dalam ranah kebudayaan bangsa Indonesia, maka sepatutnyalah konselor mengambil peran dalam penanganan kondisi ini. Peran konselor dapat diwujudkan secara nyata dalam bentuk pencegahan perilaku LGBTQ maupun penanganannya melalui pelayanan konseling dan psikoterapi.

\section{DAFTAR RUJUKAN}

Afifah, N. (2015). PERAN PEMERINTAH INDONESIA DALAM MENGATASI PERILAKU LESBIAN TENAGA KERJA WANITA DI HONGKONG (2007-2009). Jom FISIP, 1(1), 1-11. https://doi.org/10.1017/CBO9781107415324.004

Allan, B. A., Tebbe, E. A., Duffy, R. D., \& Autin, K. L. (2015). Living a Calling, Life Satisfaction, and Workplace Climate among a Lesbian, Gay, and Bisexual Population. Career Development Quarterly, 63(4), 306-319. https://doi.org/10.1002/cdq.12030

Ardi, Z. (2012). Konseling Online: Sebuah Pendekatan Teknologi dalam Pelayanan Konseling. Seminar International Konseling MALINDO 2, 235-240.

Ardi, Z., Putra, M. R. M., \& Ifdil, I. (2017). Ethics And Legal Issues In Online Counseling Services: Counseling Principles Analysis. Jurnal Psikologi Pendidikan Dan Konseling: Jurnal Kajian Psikologi Pendidikan Dan Bimbingan Konseling, 15-22.

Ardi, Z., \& Sukmawati, I. (2017). Social Media and the Quality of Subjective Well-Being; Counseling Perspective in Digital Era. Open Science Framework. October, 15. Retrieved from http://repository.unp.ac.id/11256/1/ZADRIAN ARDI-INDAH SUKMAWATI.pdf

Ardi, Z., Viola, K., \& Sukmawati, I. (2018). An Analysis of Internet Abuses Impact on Children's Moral Development. JPPI (Jurnal Penelitian Pendidikan Indonesia), 4(1), 44-50.

Ardi, Z., \& Yendi, F. M. (2017). Students Attitude Towards LGBTQ; the Future Counselor Challenges. Jurnal Konseling Dan Pendidikan, 5(2), 74-79. Retrieved from http://jurnal.konselingindonesia.com/index.php/jkp/article/viewFile/181/161

Arsita, D. (2014). POTRET KEHIDUPAN LESBIAN KOTA PEKANBARU. Jom FISIP, 1(2), 1-15. https://doi.org/10.1017/CBO9781107415324.004

Azmi, K. R. (2015). ENAM KONTINUM DALAM KONSELING TRANSGENDER SEBAGAI ALTERNATIF SOLUSI UNTUK KONSELI LGBT. Jurnal Psikologi Pendidikan \& Konseling, 1, 50-57.

BBC News. (2015). Legalisasi Pernikahan Sejenis di AS Kuatkan Gerakan di Indonesia. Retrieved from www.bbc.com/150629_trensosisal_lgbt.html

Boellstorff, T. (2004). Gay Language and Indonesia: Registering Belonging. Journal of Linguistic Anthropology, 14(2), 248-268. https://doi.org/10.1525/jlin.2004.14.2.248 
Dank, M., Lachman, P., Zweig, J. M., \& Yahner, J. (2014). Dating Violence Experiences of Lesbian, Gay, Bisexual, and Transgender Youth. Journal of Youth and Adolescence, 43(5), 846-857. https://doi.org/10.1007/s10964-013-9975-8

Davido, R. (2012). Mengenal Anak Melalui Gambar. Jakarta: Salemba Humanika.

Fifi, E. K. (2015). PERILAKU LESBIAN DALAM MEMPERTAHANKAN PASANGAN DI TEMPAT KOST DI KELURAHAN PULAI ANAK AIR BUKITTINGGI. Pendidikan Sosiologi STKIP PGRI Sumatera Barat, 1(10070226). https://doi.org/10.1017/CBO9781107415324.004

Gattis, M. N., Woodford, M. R., \& Han, Y. (2014). Discrimination and Depressive Symptoms Among Sexual Minority Youth: Is Gay-Affirming Religious Affiliation a Protective Factor? Archives of Sexual Behavior, 43(8), 1589-1599. https://doi.org/10.1007/s10508-014-0342-y

Juditha, C. (2014). Realitas lesbian, gay, biseksual, dan transgender (LGBT) dalam majalah. Jurnal Komunikasi Universitas Tarumanagara, 4(3), 22-30.

Kahija, Y. La. (2007). Hipnoterapi: Prinsip-prinsip Dasar Praktik Psikoterapi. Jakarta: Gramedia Pustaka Utama.

Kementerian Pendidikan Nasional. Undang-Undang Republik Indonesia Nomor 20 Tahun 2003 Tentang Sistem Pendidikan Nasional, XXXIII § (2003). https://doi.org/10.1007/s13398-014-0173-7.2

Mariani, O. (2013). Hubungan antara Dukungan Sosial dan Komitmen Beragama dengan Internalized Homophobia pada Lesbian. Jurnal Ilmiah Mahasiswa Universitas Surabaya, 2(2), 1-10.

Marjohan. (2012). Biografi Keilmuan Prayitno dalam Ranah Konseling dan Pendidikan. Padang: UNP Press.

Pontororing, M. (2012). KAUM LESBIAN DI KOTA MANADO. FISIP UNSRAT.

Rhomadona, S. W. (2012). PENGARUH PENGETAHUAN DAN SIKAP TENTANG KESEHATAN REPRODUKSI TERHADAP PERILAKU KESEHATAN WANITA LESBIAN DI KOTA BANDUNG. Sekolah Tinggi Ilmu Kesehatan William Booth Surabaya.

Richardson, H. B., Armstrong, J. L., Hines, D. A., \& Palm Reed, K. M. (2015). Sexual Violence and HelpSeeking Among LGBQ and Heterosexual College Students. Partner Abuse, 6(1), 29-46. https://doi.org/http://dx.doi.org/10.1891/1946-6560.6.1.29

Rubin, J. A. (2010). Introduction to Art Therapy. New York: Routledge.

S.L., R., K., F., A., L., Ridner, S. L., Frost, K., \& LaJoie, A. S. (2006). Health information and risk behaviors among lesbian, gay, and bisexual college students. Journal of the American Academy of Nurse Practitioners, 18(8), 374-378. https://doi.org/10.1111/j.1745-7599.2006.00142.x

Saputra, M. N. (2015). FENOMENA KOMUNIKASI MAHASISWI LESBIAN LABEL BUTCH DI KOTA PEKANBARU. JOM FISIP, 1(1), 1-11. https://doi.org/10.1017/CBO9781107415324.004

Siregar, C. (2013). BISEXUAL PROFILE IN PEKANBARU CITY. Jom FISIP, 53(9), 1689-1699. https://doi.org/10.1017/CBO9781107415324.004

Sumadi, N., \& Wahyu, S. (2013). Pengalaman Traumatik dan Komunikasi Keluarga Efektif dalam Pembentukan Pribadi Penyimpangan Seksual Lesbian. Fakultas Kedokteran Universitas Tanjungpura Pontianak.

Vitasandy, T. D. (2010). Konsep diri pria biseksual. Jurnal Psikologi, 3(100), 188-194.

World Health Organizaton. (2001). The World Mental Health Report: New Understanding, New Hope. Geneva: World Health Organization.

Worthen, M. G. F. (2012). Understanding College Student Attitudes toward LGBT Individuals. Sociological Focus, 45(4), 285-305. https://doi.org/10.1080/00380237.2012.712857

Yuwono, W. (2013). Relationships Development Dalam Konteks Persahabatan Yang Dibangun Antara Perempuan Lesbian Dengan Perempuan Heteroseksual. JURNAL E-KOMUNIKASI, I(3). 